\title{
PERCENTAGE OF WASTE RESULTING FROM THE CONVERSION OF THE TREE INTO LUMBER IN THE SOUTHEASTERN COAST REGION OF BRITISH COLUMBIA.
}

\author{
By J. H. Jenkins
}

CSTIMATES are frequently made as to the percentage of waste that ocC. curs in the conversion of the standing tree in the forest into seasoned lumber. Many of these estimates in the past have not been based on detailed studies and are not applicable to conditions in British Columbia. The Forest Products Laboratories of Canada, Forest Service, Department of the Interior, have for a number of years been studying wood waste and its utilization: this has included a study of the waste that occurs in logging the standing tree; of the waste that occurs in the manufacture of the log into green lumber; and of the waste that occurs in the planing and seasoning of this green lumber. The results of these studies have been set out in the report "Logging Waste in the Douglas Fir-Western Cedar Type of the Southern Coast Region of British Columbia" and in Forest Service of Canada Bulletin No. 83 "Sawmill Waste and Its Utilization in British Columbia." In this brief article an attempt is made to combine the waste percentages presented in these previous reports and to show what percentage of the standing tree is converted into the finished product in the Southern Coast Region of British Columbia.

\section{LOGGING WASTE:}

In cruising a stand of timber prior to logging, it is customary to determine the volume of the merchantable timber only, excluding small trees and the tops of merchantable trees too small to form commercial sawlogs. In the following estimates, the volume of the timber in the original stand that was cruised as merchantable is taken as representing 100 per cent. On this basis, the volume of the overlooked sawlogs, broken logs, tops, etc., left after logging as so-called "logging waste" amounts to 19.5 per cent. The volume of the original merchantable stand sent to the sawmill is therefore 80.5 per cent.

SAWMILL WASTE:

In determining the percentage of waste resulting from the manufacture of the sawlog into lumber, the cubic contents ${ }^{1}$ (exclusive of bark) of the

1In these studies it was found that 6.1 f.b.m. B.C. Log Scale is equivalent to 1 cubic foot. 
logs manufactured were taken as representing 100 per cent. On this basis the waste in manufacturing the green lumber was as follows:

$$
\begin{aligned}
& \text { Slabs, edgings, trim }=13.9 \% \text { of logs sawn } \\
& \text { Sawdust } \ldots \ldots \ldots=17.2 \% \text { of logs sawn } \\
& \text { Total Sawmill Waste }=31.1 \%
\end{aligned}
$$

This refers only to the manufacture of green lumber. There is, in addition, a reduction in the log volume of 1.2 per cent., due to the seasoning, and of 11.0 per cent., due to the surfacing of a portion of the green lumber, or a total reduction of 12.2 per cent. of the log volume due to planing mill waste.

The above percentages for sawmill waste are based on the volume of the logs sawn. They may also be expressed as a percentage of the standing tree utilized. This has been done below:-

Slabs, sawdust, etc. $=25.0 \%$ of standing tree;

Trim (seasoning and

other defects) and

shavings in planing

mill $\ldots \ldots \ldots \ldots \ldots=9.8 \%$ of standing tree.

The surfacing of lumber to obtain a pleasing appearance and uniform sizes is a necessity and increases the value of the lumber. The reduction in the volume of the lumber, but not the board-foot contents, by surfacing should not therefore be classed as avoidable waste.

Bark has been excluded in the above percentages as it is not included in the scale of the logs. When bark is included, as has been done in estimates of waste for other regions, an increase in the percentage of waste is noted, the bark materially increasing the volume of practically all pieces of slabwood, while the increase in the volume of the logs sawn due to the inclusion of bark is relatively small. When bark is included, the sawmill waste percentages for green lumber, based on the volume of the log sawn, are as follows:-

$$
\begin{aligned}
& \text { Slabs, edgings and bark }=22.2 \% \text { of volume of log sawn, } \\
& \text { (including bark) } \\
& \text { Sawdust } \ldots \ldots \ldots \ldots=16.5 \% \text { of volume of log sawn, } \\
& \text { (including bark) }
\end{aligned}
$$

\section{Total: $\quad 38.7 \%$}

When this waste is based on the volume of the standing tree, the results become:--- 
Slabs edgings and bark $=17.9 \%$ of vol. of standing tree, Sawdust $\ldots \ldots \ldots \ldots=13.3 \%$ of vol. of standing tree,

\section{Total: $\quad 31.2 \%$}

There is a slight error in this estimate as bark was not included in the logging waste.

The utilization ${ }^{1}$ of the standing tree in the Southern Coast region of British Columbia is therefore:

Waste in logging $\ldots \ldots \ldots \ldots \ldots \ldots=19.5 \%$ of stand

Slabs and edging waste in sawmill .... $=11.2 \%$ " "

Sawdust $\ldots \ldots \ldots \ldots \ldots \ldots \ldots \ldots \ldots=13.8 \%$ " "

Green lumber $\ldots \ldots \ldots \ldots \ldots \ldots \ldots \ldots=55.5 \%$ " "

Volume of Merchantable Timber: $100.0 \%$ in stand

When bark is included in the measurement of the logs and of the sawmill waste, the utilization is as follows:-

Waste in logging ............. $=19.5 \%$ of stand

Slabs, edgings and bark waste in mill ... $=17.9 \%$ " "

Sawdust $\ldots \ldots \ldots \ldots \ldots \ldots \ldots \ldots \ldots=13.3 \%$ " "

Green lumber $\ldots \ldots \ldots \ldots \ldots \ldots \ldots=49.3 \%$ " "

Volume of Merchantable Timber: $100.0 \%$ in stand

It is diffcult to compare these percentages with the utilization percent. ages quoted for other lumber manufacturing regions, unless the basis used in computing the waste percentages in the regions compared is known. It would appear, however, that the volume of waste which results from the manufacture of the standing tree into lumber in the Southern Coast Region of British Columbia is lower than that quoted for some of the other lumberproducing regions of North America.

1For information as to the extent to which sawmill waste is utilized, see Forest Service Bulletin 83 "Sawmill Waste and Its Utilization in British Columbia." 